the Departments of Account and Taxation in the Fields of the Economy, Vinnytsia National Agrarian University (21008, Vinnytsia, 3, Soniachna Str., e-mail: Natkov@i.ua).

RADCHENKO Oksana - Candidate of Economic Sciences, Leading Researcher of Financial, Credit and Tax Policy Department NSC «Institute of Agrarian Economics» (03127, Kyiv, 10, Heroes of Defense Str., e-mail: oxanarad@ukr.net).

ISHCHENKO Yana - Candidate of Economic Sciences, Associate Professor of the Departments of Account and Taxation in the Fields of the Economy, Vinnytsia National Agrarian University (21008, Vinnytsia, 3, Soniachna Str., e-mail: jana_2006@ukr.net).

КОВАЛЬ Наталия Ивановна - кандидат экономических наук, доцент кафедры учета и налогообложения в отраслях экономики, Винницкий национальный аграрный университет $(21008$, г. Винница, ул. Солнечна, 3 , e-mail: Natkov@i.ua).

РАДЧЕНКО Оксана Дмитриевна - кандидат экономических наук, ведущий научный сотрудник отдела финансово-кредитной и налоговой политики ННЦ «Институт аграрной экономики» (03127, г. Киев, ул. Героев Обороны, 10, e-mail: oxanarad@ukr.net).

ИЩЕНКО Яна Петровна - кандидат экономических наук, доцент кафедры учета и налогообложения в отраслях экономики, Винницкий национальный аграрный университет $(21008$, г. Винница, ул. Солнечная, 3, e-mail: jana_2006@ukr.net).

УДК 336.77:338.432

DOI: 10.37128/2411-4413-2021-2-9

ТЕОРЕТИЧНІ

АСПЕКТИ СУТНОСТІ

ТА ОСОБЛИВОСТЕЙ

КРЕДИТНИХ

ВІДНОСИН У

АГРАРНОМУ СЕКТОРI ЕКОНОМІКИ

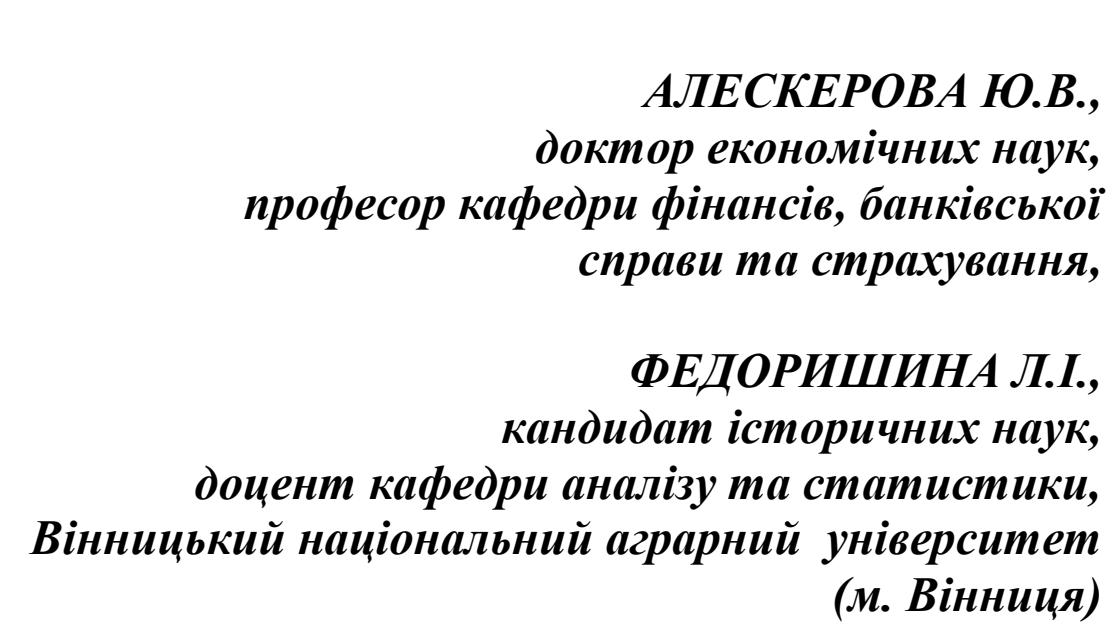

У статті деталізовано $і$ розкрито сутність поняття «кредит», досліджено еволюиійні передумови виникнення та становлення категоріального апарату кредитування, визначено характерні риси кредиту, які висвітлені представниками різних теорій. Систематизовано етапи розвитку кредитних відносин у суспільстві. Висвітлено етапи розвитку кредитних відносин, принщипи, функиії та особливості кредитування підприємств аграрного сектору економіки.

Досліджено еволючійні аспекти кредиту, як економічної категорії з позиції капіталотворчої теорії та теорії кредитного регулювання. 
Встановлено, щуо основні положення капіталотворчої теорії трактують кредит як незалежну від процесу відтворення категорію та як вирімальний фактор розвитку економіки. Розглянуто, щцо свій розвиток капіталотворча теорія набула у вигляді експансіоністської теорії кредиту, яка трунтується на положеннях про безмежність кредиту й створюваних ним депозитів і капіталу.

Визначено, щуо більш глибоко сутність кредиту розкриває теорія кредитного регулювання, яка надає кредитно-грошовій системі пріоритетну роль у розвитку економіки держави, наголошуючи на ї̈ здатності регулювати економічну систему та запобігати кризовим явищам. Встановлено, що розвиток теорій кредиту на сучасному етапі відображається в перерозподільній та фондовій теоріях.

Доведено, щчо доцільним є використання комплексного, багаторівневого підходу щцодо дослідження сутності, функиій, механізмів фукнкиіонувння кредиту та визначення його впливу на розвиток економіки держсви.

Результатом проведеного дослідження є авторське конщептуальне бачення кредиту як економічної категорії, що системно охоплює сутність, роль та функиї кредиту. Доведено правомірність існування окремого механізму кредитних відносин в аграрному секторі економіки, щуо охоплює кредитні установи, кредитний ринок, кредитну політику та самі кредитні потоки. Систематизовано сутнісні характеристики та особливості сільськогосподарського кредиту та висвітлено пріоритетні особливості об'єктів кредитування у сільському господарстві. Сформульовано та структуровано n'ять груп факторів, щзо впливають на доступність кредиту для суб'єктів господарювання у сільському господарстві у сучасний умовах.

Ключові слова: кредит, кредитні відносини, сільськогосподарський кредит, ризик, кредитор, позичальник.

Рис.: 3. Літ.: 14.

\title{
THEORETICAL ASPECTS OF THE ESSENCE AND FEATURES OF CREDIT RELATIONS IN THE AGRICULTURAL SECTOR OF THE ECONOMY
}

\author{
ALESKEROVA Yuliia, \\ Doctor of Economics Sciences, \\ Professor of the Department of Finance, Banking and Insurance
}

\author{
FEDORYSHYNA Lidiya, \\ Candidate of Historical Sciences, \\ Associate Professor of the Department of Analysis and Statistics, \\ Vinnytsia National Agrarian University \\ (Vinnytsia)
}

The article reveals the essence of credit, investigates the evolutionary prerequisites for the emergence and formation of the categorical apparatus of lending, defines the characteristic features of credit, which were studied by representatives of various theories. The stages of development of credit relations in society are systematized. The stages of development of credit relations, principles, functions and features of lending to enterprises in the agricultural sector of the economy have been investigated.

The evolutionary aspects of credit as an economic category have been investigated from the standpoint of the capital-creation theory and the theory of credit regulation.

It has been established that the main provisions of the capital-creation theory treat credit as a category independent of the reproduction process and as a decisive factor in the development of 
the economy. It is proved that the capital-creation theory received its development in the form of the expansionist theory of credit, based on the provisions on the infinity of credit and the deposits and capital created by it. It is proved that the essence of credit is revealed more deeply by the theory of credit regulation, which determines the priority role of the monetary system in the development of the state's economy, emphasizing its ability to regulate the economic system and prevent crisis phenomena. It has been established that the development of credit theories at the present stage is reflected in the redistribution and stock theories.

It has been proved that it is expedient to use an integrated, multi-level approach to the study of the essence, functions, mechanisms of the functioning of credit and to determine its influence on the development of the state economy. The result of this research is the author's conceptual vision of credit as an economic category, which systematically covers the essence, role and functions of credit. The legitimacy of the existence of a separate mechanism of credit relations in the agricultural sector of the economy, covering credit institutions, the credit market, credit policy and the credit flows themselves, has been proved. The essential characteristics and features of agricultural credit are systematized and the priority features of credit facilities in agriculture are highlighted. Five groups of factors have been formulated that affect the availability of credit for business entities in agriculture in modern conditions.

Key words: credit, credit relations, agricultural credit, risk, lender, borrower.

Fig.: 3. Lit.: 14.

\title{
ТЕОРЕТИЧЕСКИЕ АСПЕКТЫ СУЩНОСТИ И ОСОБЕННОСТЕЙ КРЕДИТНЫХ ОТНОШЕНИЙ В АГРАРНОМ СЕКТОРЕ ЭКОНОМИКИ
}

\author{
АЛЕСКЕРОВА Ю.В., \\ доктор экономических наук, \\ професор кафедры финансов, банковского дела и страхования \\ ФЕДОРИШИНА Л.И., \\ кандидат исторических наук, \\ доцент кафедры анализа и статистики, \\ Винницкий национальный аграрный университет
} (2. Винница)

В статье детализировано раскрыта сущность кредита, исследованы эволючионные предпосылки возникновения и становления категориального аппарата кредитования, определень характерные черты кредита, которые проанализировано представителями различных теорий. Систематизированьл этапь развития кредитных отночений 6 обществе. Определень этапь развития кредитных отношений, принциипы, функциии $и$ особенности кредитования предприятий аграрного сектора экономики.

Рассмотрень эволючионнье аспекты кредита, как экономической категории с позиции капиталотворческой теории и теории кредитного регулирования.

Установлено, что основные положения капиталотворческой теории трактуют кредит как независимую от прочесса воспроизводства категорию и как решающий фактор развития экономики. Доказано, что свое развитие капиталотворческая теория получила в виде экспансионистской теории кредита, основывающейся на положениях о безграничности кредита и создаваемых им депозитов и капитала. Освещено, что более глубоко сущность кредита раскрывает теория кредитного регулирования, определяющая кредитно-денежной системе приоритетную роль в развитии экономики государства, подчеркивая ее способности регулировать экономическую систему и предотвращать кризисные явления. Установлено, что развитие теорий кредита на современном этапе 
отображается в перераспределительной и фондовой теориях.

Доказано, что иелесообразным является использование комплексного, многоуровневого подхода $к$ исследованию сущности, функиий, механизмов функционирования кредита и определение его влияния на развитие экономики государства.

Результатом проведенного исследования является авторское концептуальное видение кредита как экономической категории, которое системно охватывает сущность, роль и функции кредита. Раскрыто суть правомерности существования отдельного механизма кредитных отношений в аграрном секторе экономики, охватывающая кредитные учреждения, кредитный рынок, кредитную политику и сами кредитные потоки. Систематизированы сущностные характеристики и особенности сельскохозяйственного кредита и освещены приоритетные особенности объектов кредитования в сельском хозяйстве. Сформулированы пять групп факторов, влияющих на доступность кредита для субъектов хозяйствования в сельском хозяйстве в современных условиях.

Ключевые слова: кредит, кредитные отношения, сельскохозяйственный кредит, риск, кредитор, заемщик.

Рис.: 3. Лит.: 14.

Постановка проблеми. Фундаментальним та незмінним залишається лідерство аграрного сектору національної економіки, який, із одного боку, стійко демонструє зростання експорту продукції, сталу динаміку обсягів та ефективності виробництва, а з іншого - потребує додаткових ресурсів для фінансування свого розвитку. У структурі механізму фінансового забезпечення сільськогосподарських товаровиробників саме кредитування та використання кредитних ресурсів відіграють найважливішу роль у процесах стимулювання та розвитку агровиробництва.

Зазначимо, що наявність та підвищення плато- та кредитоспроможності аграріїв суттєво розширює їх можливості у залученні кредитних ресурсів, зміцнює їх виробничий та економічний потенціал, сприяє вирішенню цілої низки соціально-економічних проблем та надає реальні перспективи щодо поступового розвитку.

Проте, акцентуємо увагу на проблемі невідповідності обсягів кредитування та отриманих сільськогосподарськими товаровиробниками результатів господарчої діяльності. Вітчизняна практика та зарубіжний досвід свідчать, що фінанси сільськогосподарських підприємств відрізняються певною специфікою i потребують постійного притоку позикового капіталу. Через тривалість виробничого циклу, сезонність виробництва i пов'язаного 3 цим характеру формування витрат і запасів у сільськогосподарських підприємств відсутні джерела для безперервного фінансування. Використання позикового капіталу дозволяє істотно розширити обсяг господарської діяльності, забезпечити більш ефективне використання власних коштів, прискорити оновлення основних фондів і т.д. У зв'язку з цим залучення і використання позикових фінансових ресурсів $\epsilon$ найважливішим аспектом господарської діяльності агровиробників, спрямованим на досягнення високих кінцевих результатів господарювання.

Стійкою тенденцією залишається відносна складність отримання кредиту сільськими товаровиробниками, тому що комерційні банки більш націлені на роботу з позичальниками, які здатні за нетривалий період часу забезпечити 
повернення кредитних ресурсів під високий відсоток. Ринок кредитних ресурсів в аграрному секторі має наявні ознаки монополістичного характеру з боку окремих кредитних організацій.

Актуальність дослідження обумовлюється необхідністю удосконалення кредитування та кредитних відносин як фактора забезпечення стійкого виробництва в сільському господарстві.

Аналіз останніх досліджень і публікацій. Дослідження змісту, функцій та особливостей кредиту й кредитних відносин висвітлено в роботах вітчизняних науковців В. Березовика, П. Бечко [6], Т. Болгар, П. Гайдуцького, О. Дзюблюка, В. Лагутіна [14], В. Міщенка та ін., а також у працях зарубіжних авторів П. Друкера, С. Роуза, Б. Райзберга, Дж. Фрідмена, С. Харріса та ін. Специфіку кредитування в аграрному секторі економіки досліджували В. Базилевич, О. Вовчак, Л. Вдовенко [11], О. Гудзь [10], I. Гончарук, Н. Грищук [12], М. Дем'яненко [13], Ю. Кліменко, П. Стецюк, П. Саблук, А. Чухно на ін. Проте зазначимо, що залишаються недостатньо дослідженими питання теоретико-методичного обгрунтування кредитних відносин у сільському господарстві.

Формулювання цілей статті. Метою дослідження $\epsilon$ вивчення та систематизація теоретичних засад та науково-методичних підходів щодо специфіки кредитування в аграрному секторі економіки.

Виклад основних результатів дослідження. М. Дем'яненко під «кредитом» розуміє економічні відносини, які об'єднують суб'єктів кредиту 3 приводу різночасного надання на платній і поворотній основі економічних благ» $[13$, с. 52]. У даний час виділяють різні форми, види і методи кредитування, що визначають характер кредитних відносин, сукупність яких утворює систему кредитування, яка має певну специфіку в сільському господарстві.

Зазначимо, що більшість дослідників наголошують та тому, що кредит це позика у грошовій або натуральній формі, яка надається однією особою іншим на умовах повернення, строковості та зі сплатою відсотків за користування [1, с. 225].

Зазначимо, що кредит, як економічна категорія, акумулює капітал, який вивільняється, обслуговує його надходження і забезпечує відтворювальний процес. Кредит прискорює процес грошового обігу, бере участь у регулюванні ринкових відносин, також він $\epsilon$ найважливішим джерелом формування оборотного капіталу практично в усіх галузях економіки.

На нашу думку, кредит як особлива форма вартісних відносин, виникає тоді, коли вартість, що вивільняється у одних економічних суб'єктів, якийсь час не використовується у господарських угодах $\mathrm{i}$ не вступає у новий відтворювальний цикл. При кредитуванні ця вартість переходить від одних суб'єктів до інших, які мають тимчасову потребу в додаткових джерелах фінансування, i, таким чином, продовжує функціонувати в рамках відтворювального процесу.

Не можна не погодитись із тим, що кредит є дуже складною економічною категорією, що, безсумнівно, обумовлює дискусію вчених-економістів стосовно 
теоретико-методологічних засад і видів кредиту та визначення його впливу на розвиток галузей економіки, зокрема, та соціально-економічних процесів у цілому. У процесі дослідження нами систематизовано основні етапи розвитку кредитних відносин (рис. 1).

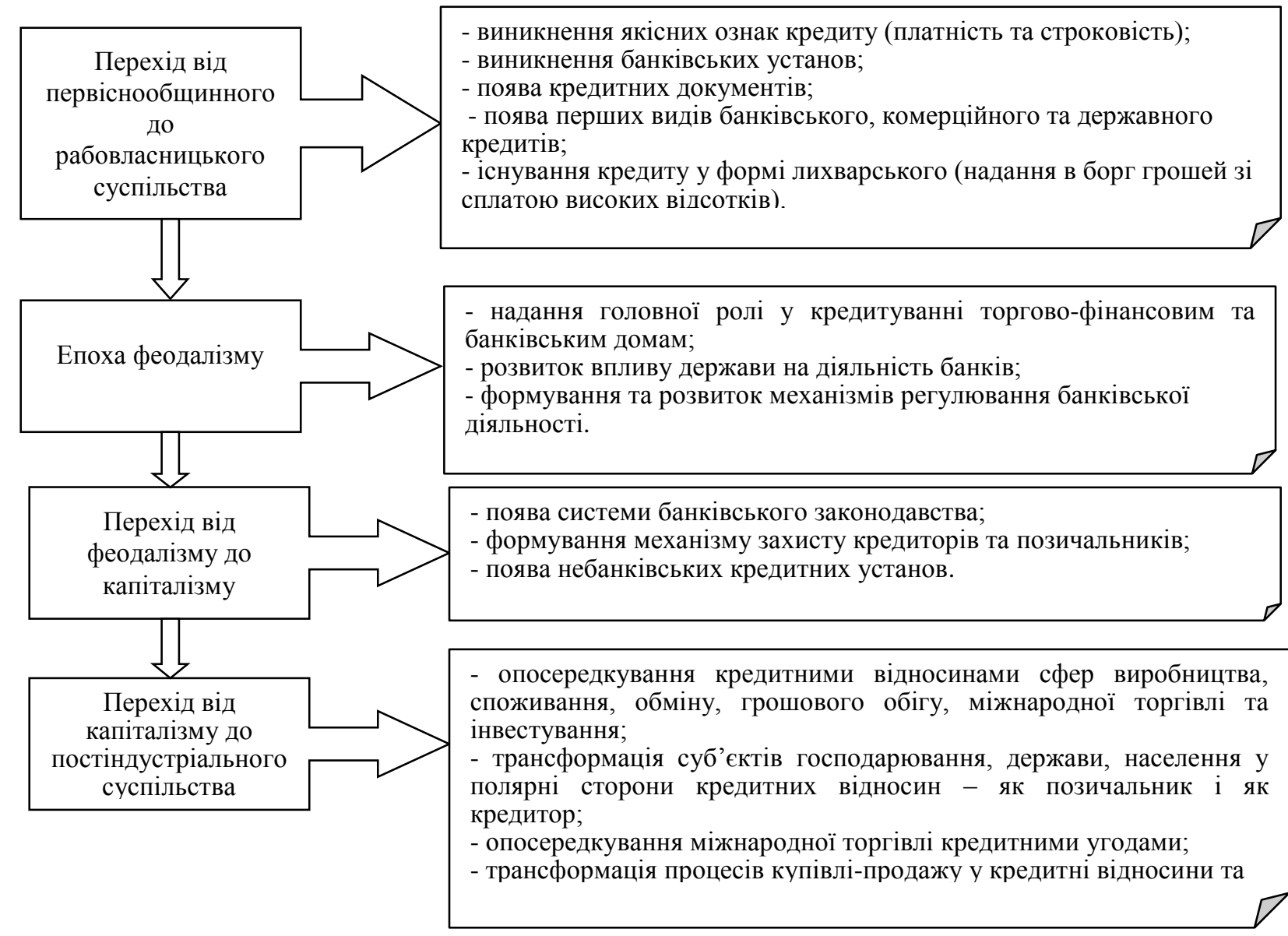

Рис. 1. Етапи розвитку кредитних відносин у суспільстві

Джерело: систематизовано авторами на основі [2, с. 20; 4, с. 35]

Опираючись на результати дослідження [2; 3], акцентуємо увагу на тому, що походження кредиту сучасна економічна теорія трактує 3 позицій двох теоретичних напрямів - натуралістичного та капіталотворчого, які у свою чергу, по різному ототожнюють роль банківського кредиту у системі економічних відносин.

Основоположники натуралістичної теорії (А. Сміт, Д. Рікардо, Дж. Мілль, Ж.-Б. Сей, А. Маршал, А. Вагнер, К. Діль) у якості об’єкту кредитування визначали натуральні блага, а сам кредит трактували як форму руху матеріальних благ, роль якого фокусується на перерозподілі цих благ у суспільстві. Банківські установи розглядались як прості посередники, що акумулюють кошти, а потім перетворюють їх у позику.

Самому кредитові відводилася пасивна роль обслуговування руху реального капіталу. Зазначалося, що кредит самостійно не створює реальної вартості. Гроші, які позичаються, - це лише технічний засіб перенесення реального капіталу від одного економічного агента до іншого.

Прихильники капіталотворчої теорії Й. Шумпетер, А. Ган, Р. Хоутрі, 
Л. Лернер, Дж. М. Кейнс, П. Самуельсон, Р. Голдсміт, Дж. Ло, Г. Маклеод, М. Фрімен, I. Кауфман та ін. надавали перевагу сфері обігу перед виробництвом, а кредит ототожнювали з грошима та багатством [4, с. 50].

Капіталотворча теорія кредиту зайняла лідируючу позицію із середини XIX ст. Її основні ідеї полягають у наступному: кредит $є$ незалежним від процесу відтворення; кредит $є$ вирішальним фактором розвитку економіки; банки є структурами, «що роблять» кредит; кредит - джерело прибутку, отже, $\epsilon$ продуктивним капіталом. Ці ідеї сформульовані шотландським економістом $\mathrm{i}$ фінансистом Дж. Ло і англійським економістом Г. Маклеодом [3, с. 23].

Подальший розвиток капіталотворча теорія кредиту отримала на початку XX ст. у роботах німецького банкіра А. Гана, англійських економістів Дж. М. Кейнса i P. Хоутри, американського економіста Е. Хансена. Методологія цієї теорії була доповнена наступними положеннями: банки виконують в економіці провідну роль; основу банківської діяльності становлять активні операції; кредит створить депозити, а отже, є джерелом банківського капіталу (ефект кредитного мультиплікатора); як джерело капіталу кредит $€$ фактором розширеного відтворення і економічного зростання [3, с. 28].

Й. Шумпетер розглядав кредит як «найважливішу умову використання існуючих факторів для створення нових виробничих комбінацій» і задля отримання в своє розпорядження засобів виробництва підприємці-новатори повинні користуватися банківським кредитом. На думку Й. Шумпетера, банки перетворюються на особливий феномен розвитку, відіграючи роль посередника між бажанням та реальною можливістю здійснити інновацію. А відсоток за користування кредитом трансформується у плату за надання таких можливостей i $\epsilon$ ціною, сплаченою за придбання нових продуктивних сил $[4$, c. 18$]$.

На нашу думку, більш глибоко сутність кредиту розкриває теорія кредитного регулювання, яка надає кредитно-грошовій системі пріоритетну роль у розвитку економіки держави, наголошуючи на іiі здатності регулювати економічну систему та запобігати кризовим явищам. Дж. М. Кейнс, як засновник цієї теорії, головну роль надавав регулюванню економіки через механізми бюджетного фінансування у бік зростання державних витрат $[3$, c. 56$]$.

У своєму розвитку дана теорія отримала два напрями. Прихильники першого напряму Е. Хансен та С. Харріс обгрунтували чітку структуру та параметри функціонування ринку капіталів та кредитної системи, а у якості регулятора обсягу капіталовкладень в економіці вважали не норму відсотка, а норму прибутку. Однією із причин невикористання виробничих потужностей і масового безробіття, на їх думку, є високий рівень відсотків по кредиту, що гальмує інвестиційні процеси. Запобігти цим явищам сприятиме збільшення емісії грошей, зниження норми відсотка та збільшення попиту [2, с. 66].

Представники неоліберального напряму А. Харт, Р. Роуз, А. Берні та Є. Адамс належать до другого напряму теорії «кредитного регулювання». Ї̈ погляди фокусувалися на неприйнятті повної зайнятості в економіці, обгрунтуванні норми безробіття та встановленні норми відсотків по кредиту на 
постійно низькому рівні, підвищенні або зниженні процентної ставки у якості одного з методів гнучкої кредитної політики [4, с. 89].

Розвиток теорій кредиту на сучасному етапі відображається в перерозподільній та фондовій теоріях [5, с. 15]. Згідно з першою теорією кредит розглядається у процесі перерозподілу тимчасово вільних грошей, їх акумуляції та переданні їх у кредит позичальникам на умовах обов'язкового повернення у встановлений термін і за умов платності. Фондова теорія трактує кредит як цілісний економічний процес.

Таким чином, існує різноманіття теоретичних підходів щодо визначення сутності кредиту, проте кожний із них не висвітлює усю багатоаспектність цієї економічної категорії.

Кредит як економічна категорія передбачає акумулювання тимчасово вільних коштів бюджету, централізованих державних позабюджетних фондів, господарюючих суб'єктів та населення для подальшої їх віддачі позичальникам на умовах повернення, платності, реального забезпечення, строковості та цільового використання [6, с. 28].

Кредит - це відносини між кредитором i позичальником із приводу зворотного руху вартості, що виражається в єдності всіх різноманітних $\mathrm{i}$ суперечливих форм прояву цих відносин [7, с. 3].

Кредит є формою руху позичкового капіталу, тобто грошових коштів, відданих у позичку за певний процент за умови повернення i задоволення протреб позичальника [5, с. 102].

Кредит - це економічні відносини, зумовлені акумуляцією тимчасово вільних коштів із використанням їх на умовах повернення та платності під час взаємовідносин, що виникають між кредитором і позичальником [9, с. 109].

Кредит - сукупність економічних відносин, що виникають між кредитором і позичальником із приводу передання вартості (майна або грошей) у позичку на умовах повернення, терміновості й платності [4, с. 69].

Кредит - це система фінансово-економічних відносин між кредитором i позичальником, яка юридично закріплена у кредитній угоді. Основою цих відносин є надання суб'єктам господарювання банківських кредитів за основі платності, зворотності, строковості та забезпеченості.

Проведений аналіз сутності економічної дефініції «кредит» дозволяє констатувати наявність суттєвої неоднозначності щодо іiі трактування. На нашу думку, найбільш оптимальним та всебічним $\epsilon$ характеристика кредиту як системи економічних відносин, що пов'язані зі зворотнім наданням коштів за умов їх строкового повернення та платності.

Як результат проведеного дослідження, вважаємо за доцільне привести концептуальне бачення кредиту як економічної категорії (рис. 2).

Під сільськогосподарським кредитом розуміють специфічну форму кредитних відносин, що характеризуються наданням грошових коштів банками i небанківськими організаціями сільськогосподарським товаровиробникам в основний і оборотний капітал у поєднанні з державним регулюванням [6, с. 39].

Багато вітчизняних дослідників трактують особливості кредитнофінансових відносин у сільському господарстві з позиції аналізу саме умов, 
термінів надання та повернення грошей, що, у свою чергу, визначає вид кредиту та його кредитного забезпечення, особливості оформлення страхування $[10$, с. $30 ; 12$, с. 614$]$.

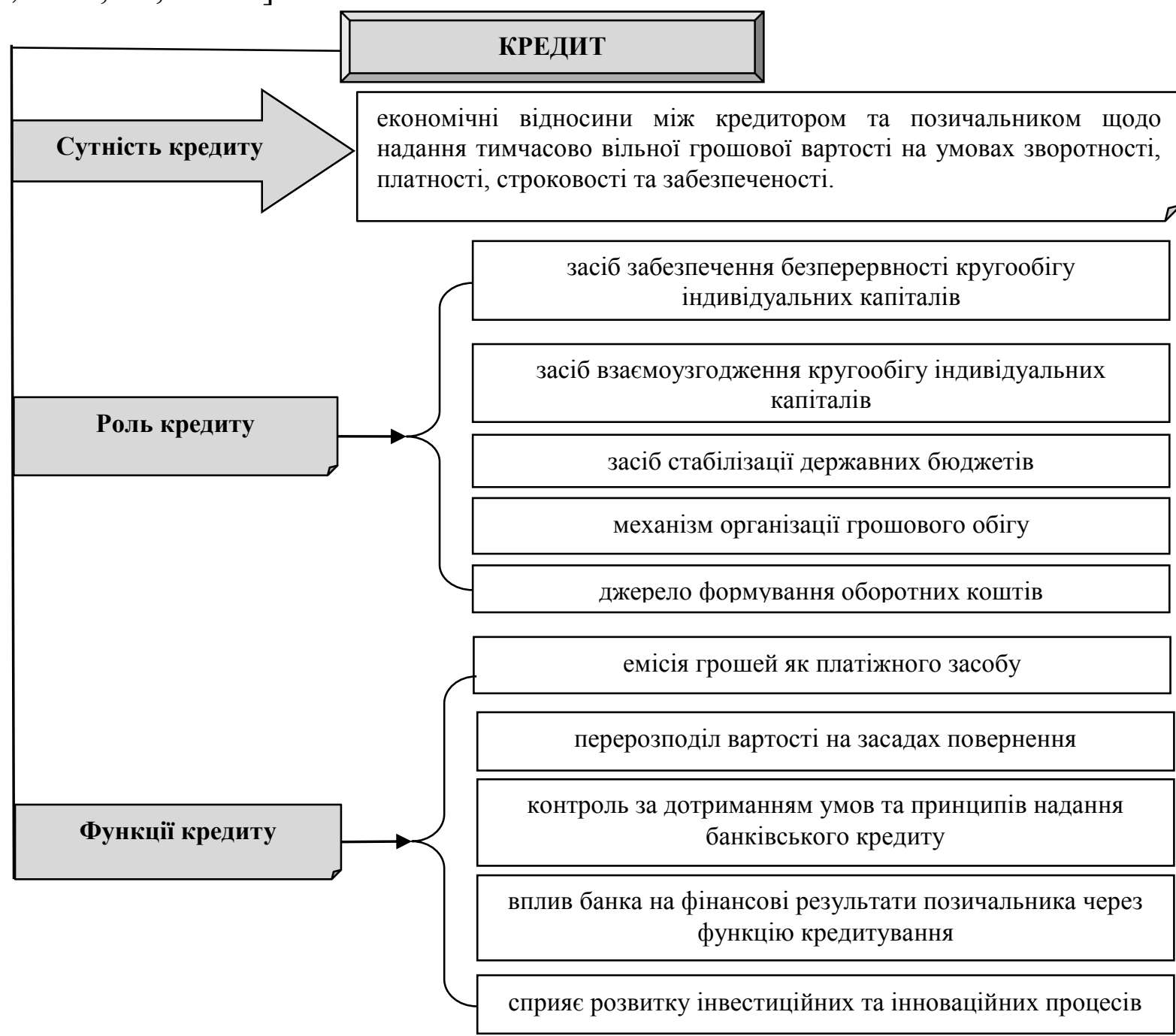

\section{Рис. 2. Сутність кредиту як економічної категорії \\ Джерело: розроблено авторами}

Дуже змістовним $є$ підхід щодо трактування системи кредитного забезпечення сільськогосподарських товаровиробників із позиції структуризації на три блоки: кредитна інфраструктура, орієнтована на обслуговування аграрного сектору; механізм кредитних відносин із комерційними банками та сам механізм кредитування [13, с. 53]. Таким чином, можна зробити висновок про правомірність існування окремого механізму кредитних відносин в аграрному секторі економіки, що охоплює кредитні установи, кредитний ринок, кредитну політику та самі кредитні потоки.

Проблема обмеженості бюджетного фінансування та бюджетної підтримки аграрного сектору економіки є достатньо тривалою та гострою, тому функції фінансування аграрних підприємств виконують кредитні установи.

Зазначимо, що економіко-організаційні відносини в аграрному секторі економіки характеризуються значною специфікою, що, у свою чергу, суттєво 
позначається на системі кредитування суб'єктів господарювання галузі. Системно сутність та особливості сільськогосподарського кредиту можна представити наступним чином (рис. 3).

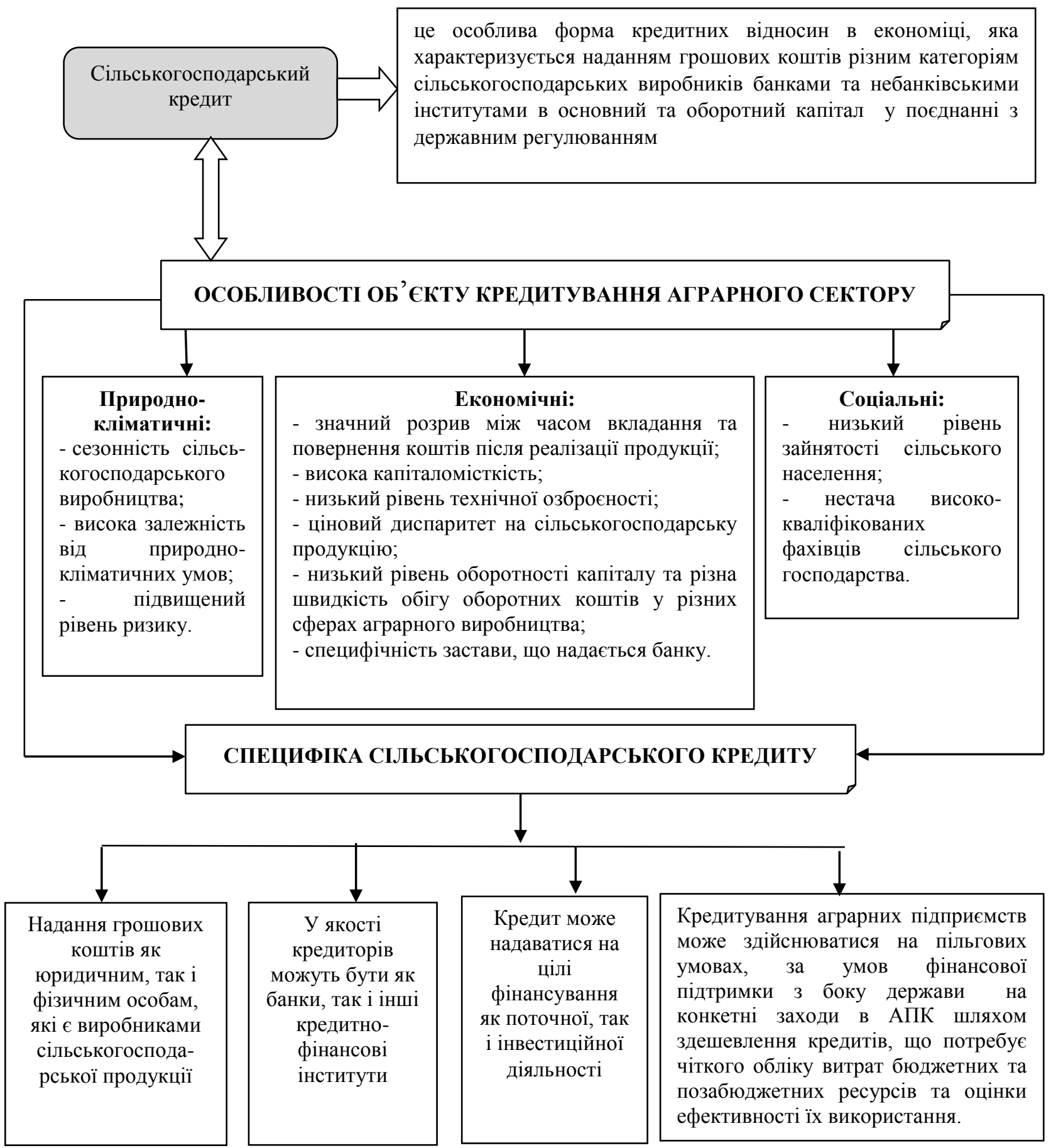

\section{Рuc. 3. Сутність та особливості сільськогосподарського кредиту}

Джерело: розроблено авторами на основі [5, с. 203; 6, с. 100]

У якості пріоритетних особливостей об’єктів кредитування у сільському господарстві, що зумовлені дією економічних факторів, виділимо наступні:

- реальна можливість повернення грошових кредитних коштів банкам лише після реалізації продукції, як правило залучення кредитів відбувається під заставу майбутнього врожаю;

- нестача власних коштів сільськогосподарських підприємств для 
фінансування поточної діяльності у наслідок достатньо високої капіталомісткості сільськогосподарської продукції та низької фондовіддачі;

- висока вартість банківських кредитів для сільськогосподарських підприємств;

- недосконалість та нестабільність ринків сільськогосподарської продукції, що характеризуються відсутністю адекватного механізму ціноутворення. Це сприяє зниженню ефективності господарської діяльності вітчизняних аграріїв та впливає на їх плато- та кредитоспроможність.

Специфіка сільськогосподарського кредитування визначається, перш за все, характером виробничих відносин. Механізм надання кредиту у максимальному розмірі повинен враховувати властивості кругообігу засобів галузі, виходячи з характерних ознак сільськогосподарського виробництва:

- уповільнена оборотність коштів на стадії виробництва у зв'язку 3 тривалим технологічним процесом;

- необхідність формування виробничих запасів, що призводить до великих витрат;

- неритмічне наростання витрат, що завершується одноразовою формою повернення коштів від реалізації продукції у кінці виробничого циклу;

- наявна потреба в страхуванні в результаті можливого негативного впливу погодних умов і стихійних лих.

Зазначимо, що сільськогосподарське виробництво потребує залучення кредитів із погашенням їх в ті періоди року, коли вихід продукції перевищить витрати на виробництво. Залучення кредитів має важливе значення при створенні сезонних запасів і витрат та при заповненні тимчасової нестачі власних оборотних коштів.

У сучасних умовах господарювання можна системно виділити наступні п'ять груп факторів, що впливають на доступність кредиту. Перша група чинників пов'язана 3 достатністю джерел погашення, яка означає, що підприємство має підстави розраховувати на отримання виручки від реалізації продукції, яка дозволяє після сплати податків покрити основну суму боргу i відсотки за кредитом.

Друга група факторів охоплює умови, що дозволяють господарюючому суб'єкту залишатися стабільним навіть при впливі несприятливих обставин і забезпечувати зобов'язання у разі недостатності джерел погашення. Великі підприємства вважаються більш стійкими, мають значний заставний потенціал. Господарство, що не має потенціалу заставного майна, має мало шансів на отримання кредиту.

Третя група факторів об'єктивно стосується кредитної історії позичальника, під якою розуміється інформація про минулі стосунки господарюючого суб'єкта з банками щодо погашення своїх зобов'язань. Якщо існують факти неповернення боргу, підприємство не зможе бути учасником кредитних відносин з банками.

До четвертої групи факторів можна віднести транзакційні витрати, які несе господарство у зв'язку з отриманням кредиту. Для крупного підприємства 
ці витрати в розрахунку на гривню наданих коштів значно нижчі, ніж для фермера, або невеликого агропідприємства.

Висновки. Кредитування аграрного сектору економіки залишається однією із головних проблем, яка гальмує розвиток сільського господарства. Головна проблема механізму фінансового забезпечення аграрного сектору економіки - це неврахування специфіки й кардинальних особливостей сільськогосподарського виробництва в процесі кредитування.

Проведений аналіз теоретичних аспектів сутності та особливостей кредитних відносин у аграрному секторі економіки дозволив системно висвітлити сутність та характерні ознаки сільськогосподарського кредиту, виявити пріоритетні особливості об'єктів кредитування у сільському господарстві, визначити фактори, що впливають на доступність кредиту для аграрних підприємств.

У результаті аналізу існуючих досліджень стану кредитування аграрного сектору визначено особливості об’єкта кредитування, зумовлені різними факторами впливу на діяльність агропромислових підприємств на підставі їх систематизації за класифікаційними факторами, а саме: природно-кліматичні, економічні, соціальні. Аналіз можливих наслідків їх впливу на кредитування надасть можливість більш поглибленого вивчення, аналізу та урахування цих особливостей у процесі оцінювання кредитоспроможності позичальника.

Існує об’єктивна необхідність удосконалення кредитної системи підтримки аграрного сектору та інструментарію кредитування аграрних підприємств, який має охоплювати цілі, завдання, проблеми оцінювання ресурсних можливостей розвитку та оцінювання ефективності результатів діяльності АПК і стати головною передумовою ефективного управління розвитком аграрного сектору економіки України.

Таким чином, розширення політики взаємодії із комерційними банками, спрощення умов надання кредитів, розвиток механізмів оптимізації їх процентної політики по відношенню до сільськогосподарських позичальників, розширення державної підтримки надання кредитів та застосування систем пільгового кредитування в змозі стати підгрунтям для поліпшення процесів фінансування аграрного сектору економіки держави та сприятиме росту його ефективності та сталого розвитку.

\section{Список використаних джерел}

1. Квіт Н. Уніфікація поняттєвого апарату відносно іпотечного кредитування. Вісник Львівського університету. Серія: Юридична. 2011. № 54. С. 224-231.

2. Версаль Н.І. Теорія кредиту: навч. посіб. Київ : Києво-Могилянська академія, 2007. 483 с.

3. Hahn L. Albert. Economic theory of bank credit. Oxford University Press, 2015. 240 p.

4. Щетинін А.І. Гроші та кредит: підручник. Вид. 2-ге переробл. і допов. Київ : Центр учбової літератури, 2006. 432 с.

5. Бандурка O.M., Глущенко В.В., Глущенко А.С. Гроші та кредит: 
підручник. Вид. 2-ге переробл. і допов. Львів : Магнолія, 2014. 368 с.

6. Бечко П.К., Герасімова Т.Т. Банківське кредитування аграрного виробництва : монографія. Умань : Візаві. Видавець Сочінський, 2013. 189 с.

7. Валенцева Н.И. Законы и закономерности развития кредита. Банковские услуги. 2010. № 12. С. 2-9.

8. Гула А.С. Теоретичні концепції кредиту: еволюція поглядів. Регіональна економіка та управління. 2016. № 1(08). С. 48-51.

9. Савлук М.І. Гроші та кредит : підручник. Київ : КНЕУ, 2011. 589 с.

10. Гудзь О.С. Кредитування і банківське обслуговування підприємств аграрного виробництва: сучасні тенденції та особливості: монографія. Київ : ННЦ IAE, 2005. $170 \mathrm{c}$.

11. Вдовенко Л.О. Кредитування в АПК : навч. посіб. Вінниця : ВНАУ, 2019. $148 \mathrm{c}$.

12. Грищук Н.В. Кредитне забезпечення функціонування сільськогосподарських підприємств в умовах сучасного економічного середовища. Східна Свропа: економіка, бізнес та управління. 2019. № 6(23). C. 613-624.

13. Дем'яненко М.Я. Кредитна політика держави щодо аграрного сектора економіки в ринкових умовах. Економіка Украӥни. 2002. № 1. С. 51-59.

14. Лагутін В.Д. Кредитування: теорія і практика : навч. посіб. Київ : Знання, 2002. 215 c.

\section{References}

1. Kvit, N. (2011). Unifikatsiia ponyattevoho aparatu vidnosno ipotechnoho kredutyvannia [Unification of the conceptual apparatus in relation to mortgage lending]. Visnyk lvivskoho universytetu. Seriia: Yurydychna - Bulletin of Lviv University. Series: Legal, 54, 224-231 [in Ukrainian].

2. Versal, N.I. (2007). Teoriya kredytu [Credit theory]. Kyiv: Vydavnichiy dim Kievo-Mohilyanska akademiia [in Ukrainian].

3. Hahn, L. Albert. (2015) Economic theory of bank credit. Oxford University Press [in English].

4. Shchetinin, A.I. (2006). Hroshi ta kredyt [Money and credit]. Kyiv: Tsentr uchbovoi literatury [in Ukrainian].

5. Bandurka, O.M., Hlushchenko, V.V., \& Hlushchenko, A.S. (2014). Hroshi ta kredyt [Money and credit]. Lviv: Mahnoliia [in Ukrainian].

6. Bechko, P.K., \& Herasimova, T.T. (2013). Bankivske kredytuvannia ahrarnogo vyrobnytstva [Bank lending for agricultural production]. Uman: Visavi. Vydavets Sochinskyi [in Ukrainian].

7. Valentseva, N.I. (2010). Zakony i zakonomernosti razvitiia kredita [Laws and patterns of credit development]. Bankovskie uslugi - Banking services, 12, 2-9 [in Russian].

8. Gula, A.S. (2016). Teoretychni kontsepsii kredytu: evolutsii pohlyadiv [Theoretical concepts of credit: the evolution of views]. Regionalna ekonomika ta upravlinnia - Regional economy and management, 1 (08), 48-51 [in Ukrainian].

9. Savluka M.I. (2011). Hroshi ta kredyt [Money and credit]. Kyiv: KNEU [in 
Ukrainian].

10. Gudz, O.E. (2005). Kredytuvannia $i$ bankivske obslugovuvannia pidpryemstv agrarnogo vyrobnytstva: suchasni tendentsii ta osoblyvosti [Lending and banking services of agar production enterprises: current trends and features]. Kyiv: NNTS, IAE [in Ukrainian].

11. Vdovenko, L.O. (2019). Kredytuvannia $v$ APK [Lending in the agroindustrial complex]. Vinnitsa: VNAU [in Ukrainian].

12. Grishchuk, N.V. (2019). Kredutne zabezpechennia funktsionuvannia silckohospodarskih pidpryemsv v umovah suchasnogo ekonomichnoho seredovyshca [Credit support for the functioning of agricultural enterprises in the modern economic environment]. Shidna Evropa: ekonomika, biznes ta upravlinnia - Eastern Europe: Economy, Business and Management, 6 (23), 613-624 [in Ukrainian].

13. Demiianenko, M.Y. (2002). Kredytna polityka derzhavy schodo ahrarnoho sektora ekonomiky v rynkovyh umovah [State credit policy on the agar sector of the economy in market conditions]. Ekonomika Ukrainy - Ukraine economy, 1, $51-59$ [in Ukrainian].

14. Lahutin, V.D. (2002). Kredytuvannia: teoriia i praktyka [Lending: theory and practice]. Kyiv: Znannya [in Ukrainian].

\section{Відомості про авторів}

АЛЕСКЕРОВА Юлія Володимирівна - доктор економічних наук, професор кафедри фінансів, банківської справи та страхування, Вінницький національний аграрний університет (21008, м. Вінниця, вул. Сонячна, 3, e-mail: aleskerovaaleskerova@gmail.com).

ФЕДОРИШИНА Лідія Іванівна - кандидат історичних наук, доцент кафедри аналізу та статистики, Вінницький національний аграрний університет (21008, м. Вінниця, вул. Сонячна, 3, e-mail: fedorishina@i.ua).

ALESKEROVA Yuliia - Doctor of Economics Sciences, Professor of the Department of Finance, Banking and Insurance, Vinnytsia National Agrarian University (21008, Vinnytsia, 3, Soniachna Str., e-mail: aleskerovaaleskerova@ gmail.com).

FEDORYSHYNA Lidiya - Candidate of Historical Sciences, Associate Professor of the Department of Analysis and Statistics, Vinnytsia National Agrarian University (21008, Vinnytsia, 3, Soniachna Str., e-mail: fedorishina@i.ua).

АЛЕСКЕРОВА Юлия Владимировна - доктор экономических наук, професор кафедры финансов, банковского дела и страхования, Винницкий национальный аграрный университет (21008, г. Винница, ул. Солнечная, 3, e-mail: aleskerovaaleskerova@gmail.com).

ФЕДОРИШИНА Лидия Ивановна - кандидат исторических наук, доцент кафедры анализа и статистики, Винницкий национальный аграрный университет (21008, г. Винница, ул. Солнечная, 3, e-mail: fedorishina@i.ua). 